\title{
Soil maps at a scale of 1:5000 as a source of soil databases taking soil variability into consideration: a case study from Czermin commune, $S$ Poland
}

\begin{abstract}
The analysis of soil spatial property variability (fuzziness) are important for the interpretation of the site-specific ecosystems not only with respect to process investigations but also for soils modelling. The objective of the study was an attempt to identify the primary parameters influencing the spatial variability of soils available without the necessity of carrying out timeconsuming and costly field and laboratory research. The research was carried out in the Czermin commune. The research included the application of geostatistical methods and interpretation of source materials, including (i) digital soil-agricultural map, (ii) annex to the soil-agricultural map at a scale of 1:5000, (iii) soil quality contours and (iv) digital terrain model. The verification of field research results (test polygon) involved the performance of vertical transect soil profiles. Genetic horizon patterns and their morphological parameters were determined. Soil samples were collected for laboratory analyses, involving the determination of the basic physical soil properties. The data were analyzed using descriptive statistics and geostatistics. The database based on soil quality contours is more detailed than that based on the soil-agricultural map, because there is no loss of important data concerning the division of land. Obtaining data concerning soil type and/or agricultural usefulness complexes would require conducting a generalisation process. Nearby soil pits from 1974 and new (2015) open pits were located. Soil profile for the open pits from 2015 were described and soil samples were taken for basic physical soil properties.
\end{abstract} class

Keywords: Soil, Spatial variability, Physical properties, Geostatistics, Agricultural usefulness complex, Contour of soil quality

\section{INTRODUCTION}

Due to shrinking natural resources and dynamic economic development, the priority of spatial policy is currently striving for obtaining spatial order and sustainable management of soil resources. Information on soils is one of the key elements influencing broadly defined sustainable development, protection of the environment and cultural heritage. The digitalisation of soil maps, development of databases on soils, and modelling of soils already has a long tradition (Minasny and McBratney 2016). The spatial variability of properties of the soil environment in terms of mathematical-physical description is also thoroughly investigated (Kaźmierowski et al. 2006). It can be considered on various levels, e.g. of the dynamic or spatial variability of chemical properties $(\mathrm{pH})$ in time concerning, among others, granulometric composition (Usowicz et al. 2004). Traditional analogue maps present soil conditions by means of discontinuous classes, e.g. soil quality classes, types of soil and agricultural usefulness complexes (Cierniewski 1987). Attempts are currently being made to develop optimal inference models aimed at the presentation of the variability (fuzziness) of soil spatial propertie by means of continuous classes (Vasu et al. 2017).
The applied models are based on combining information from direct research on soils with information included in correlated environmental data and remote sensing images (Behrens and Scholten 2006). Their advantage is the possibility of introduction of the uncertainty of the expected results to the model and tracing error propagation throughout the modelling process, from the assessment of the accuracy of source data on soils, through the accuracy of the considered environmental factors, to the assessment of the inference system (Carre et al. 2007, Bombasaro and Kasper, 2016). New technologies such as global position system (GPS) and geographic information system (GIS) allowed for more detailed reflection of soil properties (Teng et al. 2017), and remote sensing techniques - collection of high amounts of georeference data related to soil properties contributing to the development of databases on soils (Wade et al. 1996, Białousz et al. 2010, Bong et al. 2014, Brevik et al. 2016).

So far, both in Europe and in the world, many ways of preparing of soil maps have been developed, including data on their properties and therefore quality and usefulness of soils for the introduction and development of various functions (Gooley et al. 2013). 
These are usually digital maps or databases based on medium and small-scale maps, most often maps of soil typologies in combination with their properties (European Commission, 2005). Large-scale maps (1:5000 and 1:10 000) are prepared locally depending on needs, primarily for fiscal (Behrens and Scholten 2006) and land appraisal purposes (website 1,2012). This cannot however be considered a global solution or complex approach. For example, financial assistance in the scope of subsidies for agricultural production covering areas with unfavourable land management conditions in the European Union is regulated by each Member State based on national maps of soil quality. There is no uniform system or database on soils throughout the Community (Dobers et al. 2010, Nussbaum et al. 2011). Preparing soil maps at a scale of 1:5000 ensures detailed, very desirable data, which could provide the basis for the development of a uniform, common-standard system. Their preparation, however, requires enormous financial investment (Panagos et al. 2011). Due to this, increasingly better methods are sought to prepare this type of digital maps and databases on soils, which would become the basis for drawing broader conclusions.

The aim of the study was to assess the usefulness of soil-agricultural and classification maps in the scale 1:5000 in the context of identification of factors determining spatial soil variability. This is particularly important from the point of view of costs and reliable determination of the extent of soil contours, which is labour consuming.

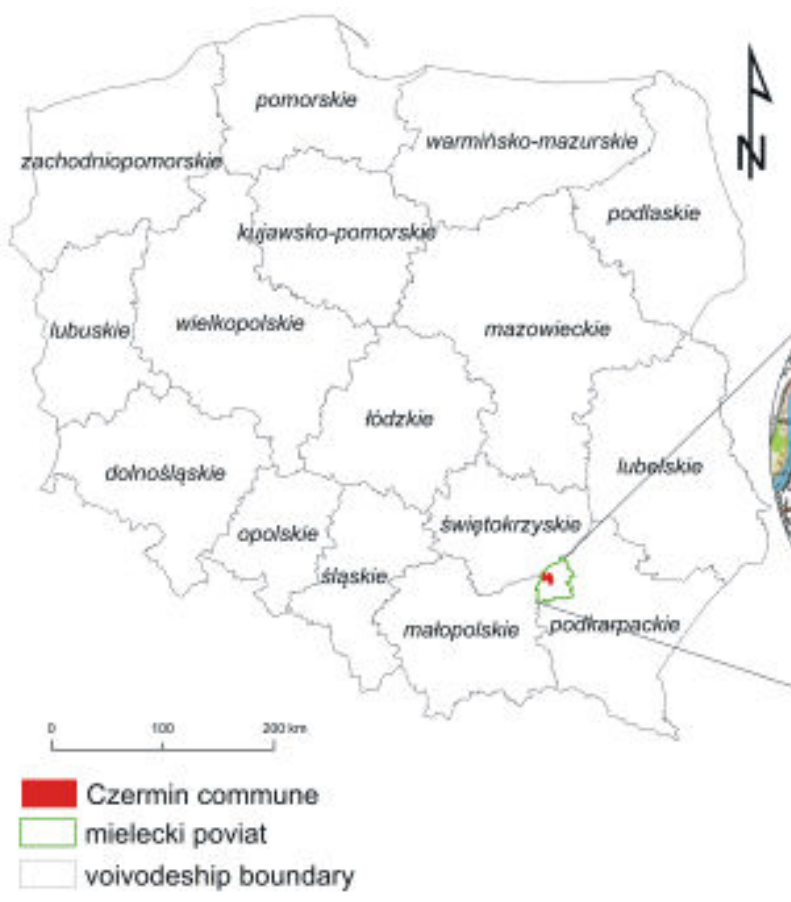

\section{STUDY AREA AND MATERIALS AND METHODS}

The research was carried out in the commune Czermin area (Fig. 1). This is a rural location in the north-western part of the Mielec district. It is among the smallest communities of the Podkarpackie voivodship with a population of 6984 (data from 2013). To the north, commune Czermin borders Borowa and to the south with Wadowice Górne, to the east with Mielec and its western boundary is also that between the Podkarpackie and Małopolskie voivodships. It is located in the catchment area of the Vistula River and its right bank tributaries Nowy Breń and Stary Breń (Strategy 2014).

The basic economy in Czermin is agriculture. Out of the total area of commune Czermin is 8021 ha of which 6084 ha is arable land. More than $75 \%$ of the area constitutes arable land, $18 \%$ - forests and the remaining is particularly occupied by residential and urbanised areas and roads (6\%). In terms of climate, the commune has favourable agricultural conditions with soils of varied value and usefulness for agricultural production. A considerable area is occupied by highly fertile soils included to soil quality classes I-III. The result of the assessment of the agricultural production space for the commune is positive. The mean index of quality of agricultural production space according to Institute of Soil Science and Plant Cultivation State Research Institute in Puławy amounts to 72.9 points (at a scale of 19.5-120 points) (Krasowicz et al. 2011). The index of agricultural valorisation of agricultural production space assessing

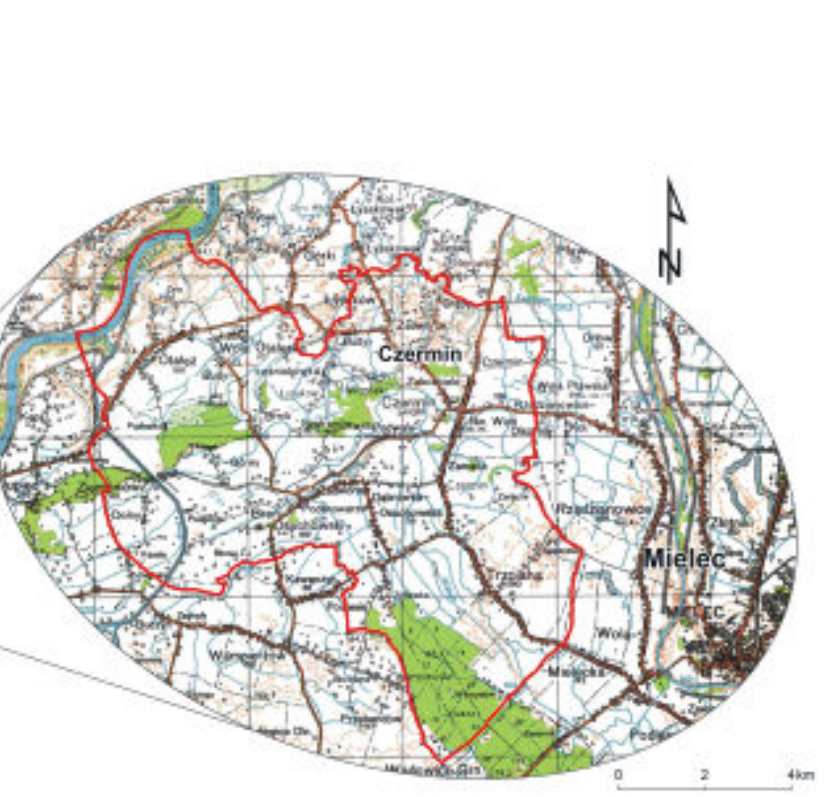

FIGURE 1. Location of the study area, own elaboration 
particular elements of the environment, namely soil, climate, water conditions and relief is higher than the national average, and approximate to the average for the Mielecki poviat and Podkarpackie voivodship. The highest contribution in commune Czermin is provided by soils of soil quality class IV at more than $57 \%$. The largest complexes of the soils occur in the Czermin and Trzciana villages. Of the total area of arable land, soils of class II quality constitute $16 \%$ and $20 \%$ class III. The soils serve the cultivation of plants with high soil requirements. Arable land is dominated by cultivated fields $(89.75 \%)$. The remaining land is occupied by pastures $(6.87 \%)$, meadows $(2.82 \%)$ and orchards $(0.56 \%)$ (Strategy 2014$)$.

The scope of this research covered concept works preceded by the analysis of studies to date concerning the assessment of spatial variability of soils, which provided the basis for the determination of the primary factors influencing fuzziness of soils. Moreover, the research included the application of geostatistical methods (Inverse Distance Weighted, Natural Neighbour, Simple Kriging) and interpretation of source materials including: (i) digital soil-agricultural map, (ii) annex to the soil-agricultural map at a scale of 1:5000, (iii) soil quality contours and (iv) digital terrain model. During the experimental work, all three geostatistical methods were used but ultimately the Natural Neighbour method was chosen for interpolation due to the location and properties of the data study and the best estimation result. The verification of field research results (test polygon) involved the performance of soil profiles with vertical soil transect. In 2015, the authors carried out field studies that included the determination of generic horizon pattern sequence and their morphological parameters. Soil samples were collected for laboratory analyses, involving the determination of the basic physical soil properties using standard methods. Laboratory analyses (genetic horizon, sampling depth, granulometric composition) were conducted to compare the data obtained from the annex to the soil-agricultural map at a scale of 1:5000 made in 1970. The soil profiles were located in the vicinity of those performed and described in 1974. Interpolation of factors determining the spatial variability of soils was attempted.

Based on data obtained from the Central Voivodship and Poviat Geodetic and Cartographic Documentation Centre, a database was developed for the Czermin commune, including:

(1) Soil quality contours from the land and building register including descriptive data on type of land.

(2) Digital soil-agricultural map were prepared based on analogue maps at a scale of 1:5000, including: - soil-agricultural contours (polygons) and descriptive data included in the table of attributes, in particular, agricultural usefulness complexes.

(3) Results of laboratory analyses from 1974 performed for the soil-agricultural map at a scale of 1:5000 soil profiles (points) and descriptive data included in the table of attributes, containing a reference to the number of laboratory analyses from 2015.

(4) Web map services (WMS):

- topographic map,

- orthophotomap.

(5) Database of Topographic Objects (DTO).

(6) Raster form of Digital Terrain Model (DTM) in the hypsometric version.

(7) Raster form of DTM in the shaded version, digital terrain model:

- with the mean error value not higher than $0.20 \mathrm{~m}$ in the ASCII XYZ format,

- with mean error value from 0.80 to $2.00 \mathrm{~m}$ in the ESRI TIN format.

(8) Data from the Bank of Local Data of Central Statistical Office.

The schematic diagram of methodological procedure is given in Figure 2. The research covered land with a total area of 8020 ha including 13786 soil quality contours and 12353 soil-agricultural contours from the soil-agricultural map.

For the purpose of verification of the spatial variability of soils, defined as fuzziness of stable in time properties, particularly of the grain structure of the bedrock, field and laboratory research was conducted on soil samples with different properties. The conducted research permitted the determination of factors affecting soil fuzziness to the greatest extent.

A number of spatial analyses were carried out, resulting in the preparation of a map of the granulometric composition of the surface soil layer, spatial variability of soils from two examples/objects, and fuzziness of soils with consideration of land relief. Based on data included in descriptions of the soil profiles and contours from the soil-agricultural map, each soil profile was ascribed with a type of soil. A database was developed for the granulometric structure of the surface soil layer. Then, interpolation was performed by means of the deterministic "natural neighbour" method in GIS software.

The spatial variability of soils was determined by means of buffers around soil quality contours $(0.5 \mathrm{~m})$ using tools of buffer analyses implemented in GIS software. The same method was applied to determine 


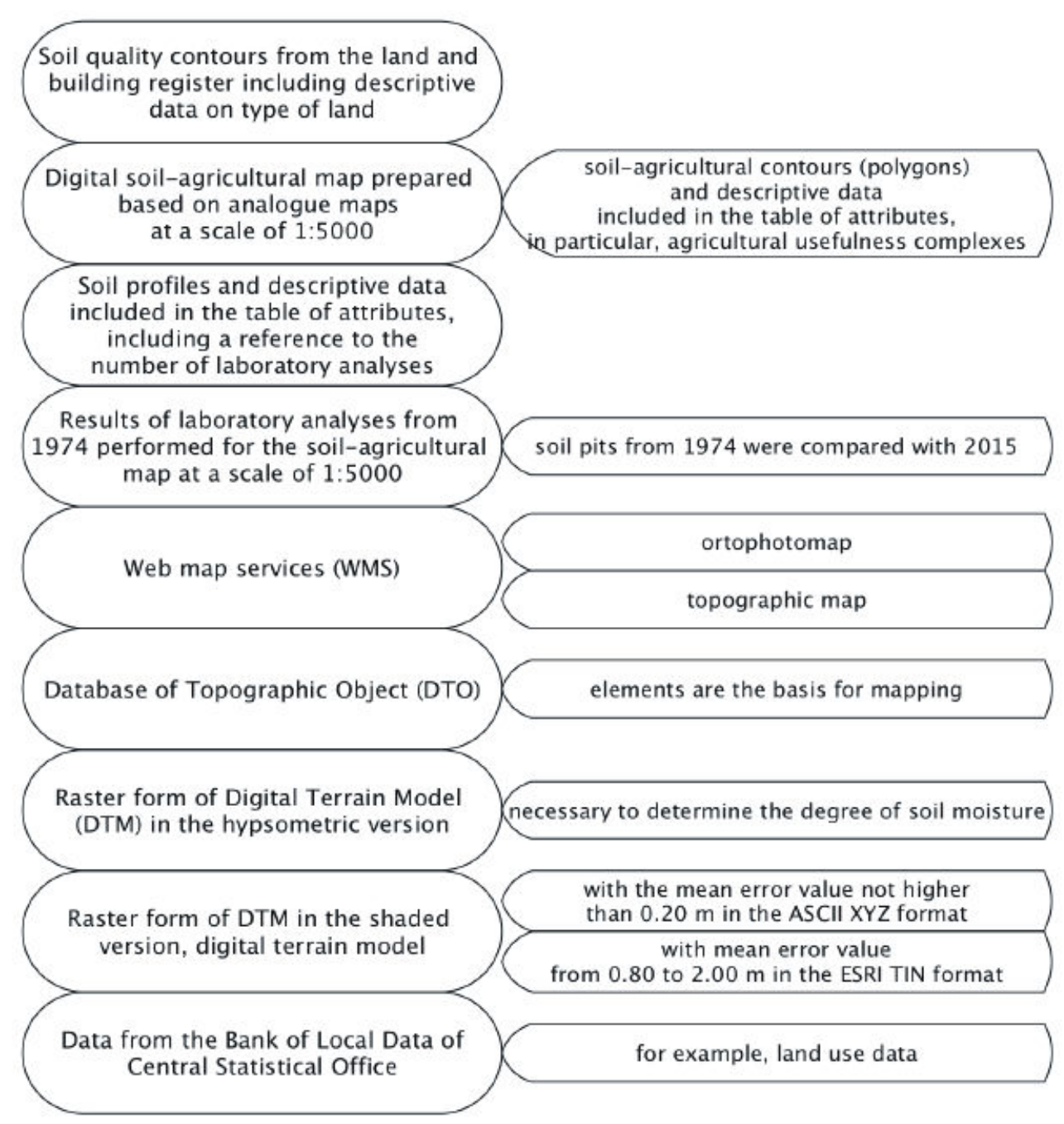

FIGURE 2. Diagram of methodological procedure, own elaboration

a buffer with a width of $15 \mathrm{~m}$ around soil-agricultural contours. Next, a random sample of 15 contours was selected, and the statistics of the common areas of the buffers were calculated. Buffers around soil quality contours $0.5 \mathrm{~m}$ was adopted due to the fact that contours like land use contours belong to the third group of field details, whose unambiguous identification in the field is difficult and additionally subject to the subjective assessment of the person performing the measurement. The geodetic situational surveying of these details is carried out in a way that ensures the location of the situational point relative to the nearest horizontal points of the geodetic control network and the surveying network with an accuracy not less than $0.5 \mathrm{~m}$ (Rozporządzenie 2011). On the other hand, a $15 \mathrm{~m}$ buffer for soil-agricultural contours was adopted because soil-agricultural maps developed in the 1960s are characterized as accurately as possible by the spatial distribution of soils.
However, the accuracy of their course is estimated at about 10-30 m (Kuźnicki et al. 1979). Uncertainty in the course of the boundaries results from the accuracy of the application of soil-agricultural contours and the failure to take into account the fluidity of changes in the soil cover both in the geographical space and the space describing the attributes. Due to the fact that determining the range of the soil quality contours with an accuracy of $0.5 \mathrm{~m}$, is very difficult to determine in the case when the type of land use is not changed, it was assumed that the buffer is $0.5 \mathrm{~m}$ and not $0.25 \mathrm{~m}$. For soil-agricultural contours a buffer of $15 \mathrm{~m}$ was assumed for $30 \mathrm{~m}$ plotting accuracy due to the fact that their accuracy may be very different.

In the next sample, analogically, pairs of 50 contours were selected (contours with overlapping boundaries were selected on purpose), and analogical measures were performed (Table 1). 
The following maps were prepared based on the database of the land and building register and soilagricultural database (these maps were the basis for another analyses): (1) soil-agricultural map, (2) location of soil profiles, (3) soil quality classes, (4) types of soils, (5) land use and (6) particle-size soil distribution.

A number of spatial analyses were also performed resulting in the preparation of the following maps:

- particle size of the surface soil layer - range of particular classes,

- spatial soil variability - ratio of the area of buffers of arable land to the area of buffers of soil types; sample of 15 contours,

- spatial soil variability - ratio of the area of buffers of arable land to the area of buffers of types of soils; sample of 50 contours.

Based on the analyses of source materials, areas were preliminarily designated in which the phenomenon of fuzziness of soils occurs.

TABLE 1 . The statistics of random sample of 15 and 50 contours of the common areas of the selected buffers

\begin{tabular}{llll}
\hline $\mathbf{1 5}$ contours & & & \\
\hline Object & $\begin{array}{l}\text { Soil quality } \\
\text { classes } \\
\text { buffer }\end{array}$ & $\begin{array}{l}\text { Soil } \\
\text { contours } \\
\text { buffer }\end{array}$ & $\begin{array}{l}\text { Intersection } \\
\text { of buffers }\end{array}$ \\
\hline Area $\left[\mathrm{m}^{2}\right]$ & 1661 & 37361 & 1321 \\
\hline $\begin{array}{l}\text { Percentage share of buffer } \\
\text { area of agricultural land } \\
\text { included in soil buffers }\end{array}$ & $80 \%$ & & \\
\hline $\begin{array}{l}\text { The number of agricultural } \\
\text { land under consideration }\end{array}$ & 15 & & \\
\hline $\mathbf{5 0}$ contours & & & \\
\hline Area [m²] & 4274 & 94092 & 3909 \\
\hline $\begin{array}{l}\text { Percentage share of buffer } \\
\text { area of agricultural land } \\
\text { included in soil buffers }\end{array}$ & $91 \%$ & & \\
\hline $\begin{array}{l}\text { The number of agricultural } \\
\text { land under consideration }\end{array}$ & 50 & & \\
\hline
\end{tabular}

\section{RESULTS AND DISCUSSION}

Factors affecting the spatial variability of soils to the greatest extent included bedrock and land relief, determining the physical and physio-chemical soil parameters. Based on soil contours from the digital soil-agricultural map and soil quality contours, the range of belts of soil variability was determined. The percent contribution of ranges of areas of soil variability (areas of buffers of soil quality contours in reference to soil contours from the soil-agricultural map) for all contours amounted to $31 \%$, resulting in the total area of $22902 \mathrm{~m}^{2}$. For the selected of random
15 contours, $80 \%$ contribution of the area of buffers was obtained in comparison to the assumed (hypothetical) area. In the intentionally selected contours (the best fitting), a cover (conformity) contribution at a level of $91 \%$ was obtained. This corresponds with the area of the buffer of $3909\left(\mathrm{~m}^{2}\right)$ in comparison to $144543 \mathrm{~m}^{2}$ of the area of the analysed contours. These results suggest that the application of soil-agricultural maps in combination with soil quality contours offers a possibility of determination of an approximate range of soil fuzziness. One of the primary factors determining physical and physio-chemical properties of soils is bedrock. Therefore, data obtained from the maps were verified in field research based on the granulometric composition.

The obtained results largely confirmed the credibility of data obtained from soil-agricultural soils at the scale of 1:5000 and other source materials. Nonetheless, no conformity of the contour with actual conditions occurs among the analysed soil contours. The contour marked with number 181105_2.0047 ends with a sharp boundary corresponding with the boundary of the area (Fig. 3). This is not in accordance with the land relief or with soil properties.

Knowledge about soil characteristic is indispensable for description, interpretation and prediction of the course of physical, chemical and biological processes and modelling these processes requires representative data (Bieganowski et al. 2013). Soil maps were desirable for purposes of land valuation for taxation, agronomic planning and even in military operations (Brevik et al. 2016). It should be emphasised that soil-agricultural maps were based on the existing classification maps. Maps of this kind, pursuant to the technical manual on soil classification of land, were determined with an accuracy of $10 \mathrm{~m}$ (Strzemski et al. 1964). In less diverse land, however, where a change of class does not result from a change in evidently observed physiographic elements like slope refraction, valley edge, evident change in moisture or boundary of land use, the accuracy of ranges specified on the map is lower than that postulated in the manual and can decrease to $30 \mathrm{~m}$. Therefore, the actual accuracy of ranges of contours on the soil-agricultural map can be even lower (Kuźnicki et al. 1979). The field research permitted the determination of the range of the variability with an accuracy to $5 \mathrm{~m}$ in one case and with an accuracy varying from 10 to $15 \mathrm{~m}$ in three remaining cases. As emphasised by De Gruijteret et al. (2011), the introduction of a fuzzy boundary will allow for obtaining, contrary to appearances, more credible data. The designated areas where certainty regarding the content of the map reaches almost $100 \%$, but also for areas with uncertain 


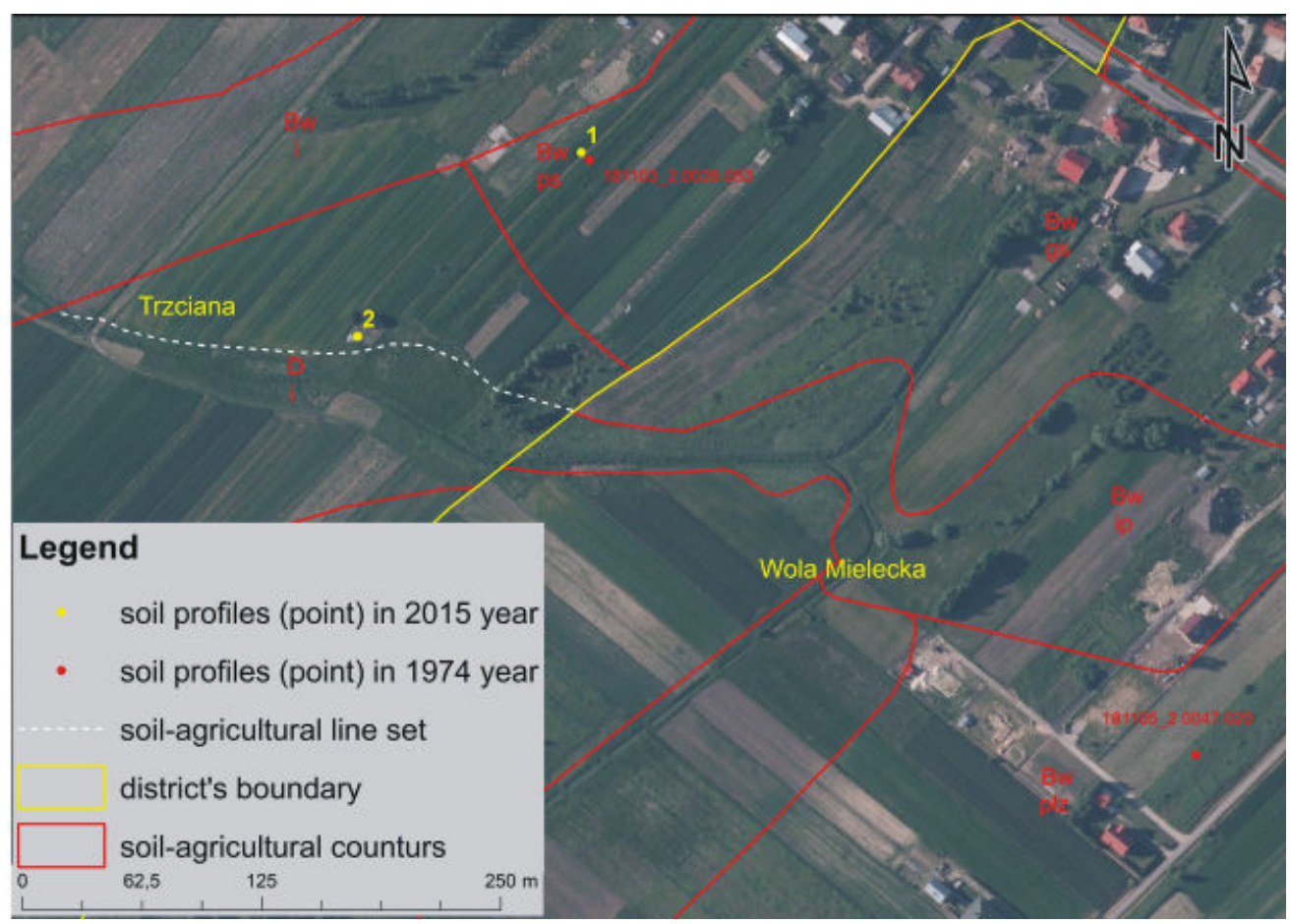

FIGURE 3. Example discrepancy of the boundary of a soil-agricultural contour with data in the field, own elaboration

boundaries, should allow for obtaining more credible data on soil conditions. This results from both the continuity of the phenomenon, and from the low level of detail of the map itself (Bielska and Jaroszewicz 2012).

Indices of the assessment of soil quality include many physical parameters strongly related to its functions like depth of soil and the root zone, thickness of the humic horizon, soil colour, granulometric composition, soil structure, water resistance of soil aggregates, density, crusting, water capacity, useful water retention, infiltration, aeration, surface runoff of water, rill flow, facility of cultivation, conditions for rising of plants, etc. (Reynolds et al. 2002, Shukla et al. 2006). Some of those parameters are permanent and cannot be changed by land use, e.g. the granulometric composition. Others can be improved through relevant cultivation measures.

The most important physical soil parameters include granulometric composition, structure, soil density, porosity, compactness, swelling and shrinking as well as functional properties related to water, air and temperature (Warrick 2002, Usowicz et al. 2011). The knowledge of the properties related to water and air is necessary for the interpretation and forecasting of the course of all physical, chemical and biological processes occurring in soils (Walczak et al. 2002, Kutilek 2006). Due to this, the preparation of maps of soil moisture based on photogrammetric materials will contribute to a more precise assessment of the range of spatial variability of soils.

Physical properties of cultivated soils are very variable in the vegetative season because they depend not only on the granulometric composition, mineralogical composition of the soil and content of organic matter but also on the performed agrotechnical measures, species of the crops and meteorological conditions. The determination of the physical state of soils occurs based on various parameters, many of which have no specified threshold values permitting the assessment of the physical soil quality.

Organic matter improves the fertility of soils through many physical processes. Organic matter can retain 20 times more water in comparison to its weight. The soil organic matter increases and stabilises soil structure, precipitation water retention capacity, cation exchange capacity of soil and circulation of elements in the soil-water environment. It regulates the rate of infiltration of precipitation water and reduces the susceptibility of soils to crusting, erosion, and soil density. Moreover, it affects its thermal properties and heat flow and accumulation. It increases the content of organic matter. Particularly in moist soil, it makes the colour darker, increasing the absorption of solar energy due to a lower albedo. Even a slight loss of soil organic matter can cause a 
deterioration of the structure and lowering of the physical soil quality (Maciejewska 1994, Kwiatkowska-Malina 2009). Therefore, in addition to granulometric composition, the content of organic matter in soil is the key attribute of the physical soil quality. Studies on the spatial soil variability should undoubtedly cover the content and properties of soil organic matter. Due to the pilot character of the research, however, it was limited to the basic physical properties (granulometric composition) of soils (Table 2).

On the basis of soil profile morphological analysis including colour, grain size, structure and depth of occurrence of individual levels and the nature of transitions between them, the studied soils were classified as brown soils (Polish Soil Classification, 1989).

Comparison of the results of research on the basic physical properties of soils (Table 2) with the data obtained from the annex to the soil and agricultural map in scale 1: 5,000 from 1974 indicates that the soil properties have not changed significantly over 40 years and remained at a similar level as typical acid brown soils. The greatest diversity of studied soil properties were observed in the profile 1 . This could be due to erosion, which are particularly severe on agricultural soils.

The research showed that soil-agricultural maps constitute a very valuable source of data on soil conditions. Due to the lack of their validity and low level of detail, however, data obtained are inaccurate. Therefore, it is advisable to perform further research leading to the development of a uniform model and database on soils, whereas two courses of procedure are the most justified:
1. Application of data obtained based on the existing materials, including soil-agricultural contours (digital soil-agricultural map), generally rarely updated with accuracy varying from 10 to 30 (m) (Kuźnicki et al. 1979) supplemented with data from:

a) soil quality contours (from the database of the land and building register),

b) digital terrain model,

c) soil moisture maps developed on the basis of photogrammetric data.

2. Application of data obtained based on the existing materials, including soil quality contours (from the database of land and buildings registers) updated by law determined with an accuracy of $0.5 \mathrm{~m}$ and supplemented with data from:

a) data from the soil and agricultural map and annex

b) digital terrain model,

c) soil moisture maps developed on the basis of photogrammetric data

Based on this kind of data, modelling of spatial variability of soils is proposed using known methods, including geostatistical methods, fuzzy functions and multi-criteria analyses. The consideration of maps of soil moisture permitted the confirmation of the range of spatial soil property variability resulting from stable properties such as bedrock and land relief by means of properties changing dynamically in time (soil moisture). Land relief and spatial distribution of the type of bedrock determine soil moisture visible both in the field and in the available photogrammetric materials (Fig. 4). Moreover, successive supplemen-

TABLE 2. Comparison of physical soil properties in 2014 and 1974

\begin{tabular}{|c|c|c|c|c|c|c|c|}
\hline \multicolumn{4}{|l|}{2014} & \multicolumn{4}{|l|}{1974} \\
\hline No profile & $\begin{array}{l}\text { Genetic } \\
\text { horizon }\end{array}$ & $\begin{array}{l}\text { Sampling depth } \\
\text { (cm) }\end{array}$ & $\begin{array}{l}\text { Granulometric } \\
\text { composition }\end{array}$ & No profile & $\begin{array}{l}\text { Genetic } \\
\text { horizon }\end{array}$ & $\begin{array}{l}\text { Sampling depth } \\
(\mathrm{cm})\end{array}$ & $\begin{array}{l}\text { Granulometric } \\
\text { composition }\end{array}$ \\
\hline \multirow[t]{4}{*}{1} & Ap & $0-30$ & SiL - silt loam & 53 & Ap & $0-30$ & $\begin{array}{l}\text { LVFS - loamy } \\
\text { very fine sand }\end{array}$ \\
\hline & ApBbr & $30-50$ & $\mathrm{Si}-$ silt & & $\mathrm{Bbr}$ & $30-60$ & $\begin{array}{l}\text { LVFS - loamy } \\
\text { very fine sand }\end{array}$ \\
\hline & $\mathrm{BbrC}$ & $50-70$ & $\mathrm{Si}-$ silt & & $\mathrm{C}$ & $60-80$ & $\mathrm{~S}-$ sand \\
\hline & $\mathrm{D}$ & $>70$ & $\mathrm{~S}-$ sand & & $\mathrm{C}$ & $>80$ & $\mathrm{~S}-$ sand \\
\hline \multirow[t]{3}{*}{2} & Ap & $0-30$ & $\mathrm{SiCL}$ - silty clay loam & 30 & Ap & $0-25$ & $\mathrm{~L}-$ loam \\
\hline & $\mathrm{Bbr}$ & $30-70$ & SiCL - silty clay loam & & Bbr & $25-60$ & $\mathrm{~L}-$ loam \\
\hline & $\mathrm{C}$ & $>70$ & SiCL - silty clay loam & & $\mathrm{C}$ & $>60$ & $\mathrm{~L}-$ loam \\
\hline \multirow[t]{2}{*}{3} & Ap & $0-30$ & $\mathrm{Si}-$ silt & 52 & Ap & $0-35$ & $\mathrm{Si}-$ silt \\
\hline & $\mathrm{Bbr}$ & $>30$ & $\mathrm{Si}-$ silt & & Bbr & $35-50$ & $\mathrm{Si}-$ silt \\
\hline \multirow[t]{3}{*}{4} & Ap & $0-30$ & $\begin{array}{l}\text { LVFS - loamy } \\
\text { very fine sand }\end{array}$ & 26 & Ap & $0-25$ & $\begin{array}{l}\text { LVFS - loamy } \\
\text { very fine sand }\end{array}$ \\
\hline & $\mathrm{BbrC}$ & $30-70$ & $\mathrm{~S}-$ sand & & Bbr & $25-50$ & $\mathrm{~S}-$ sand \\
\hline & $\mathrm{D}$ & $>70$ & $\mathrm{~S}-$ sand & & $\mathrm{C}$ & $>50$ & $\mathrm{~S}$ - sand \\
\hline
\end{tabular}




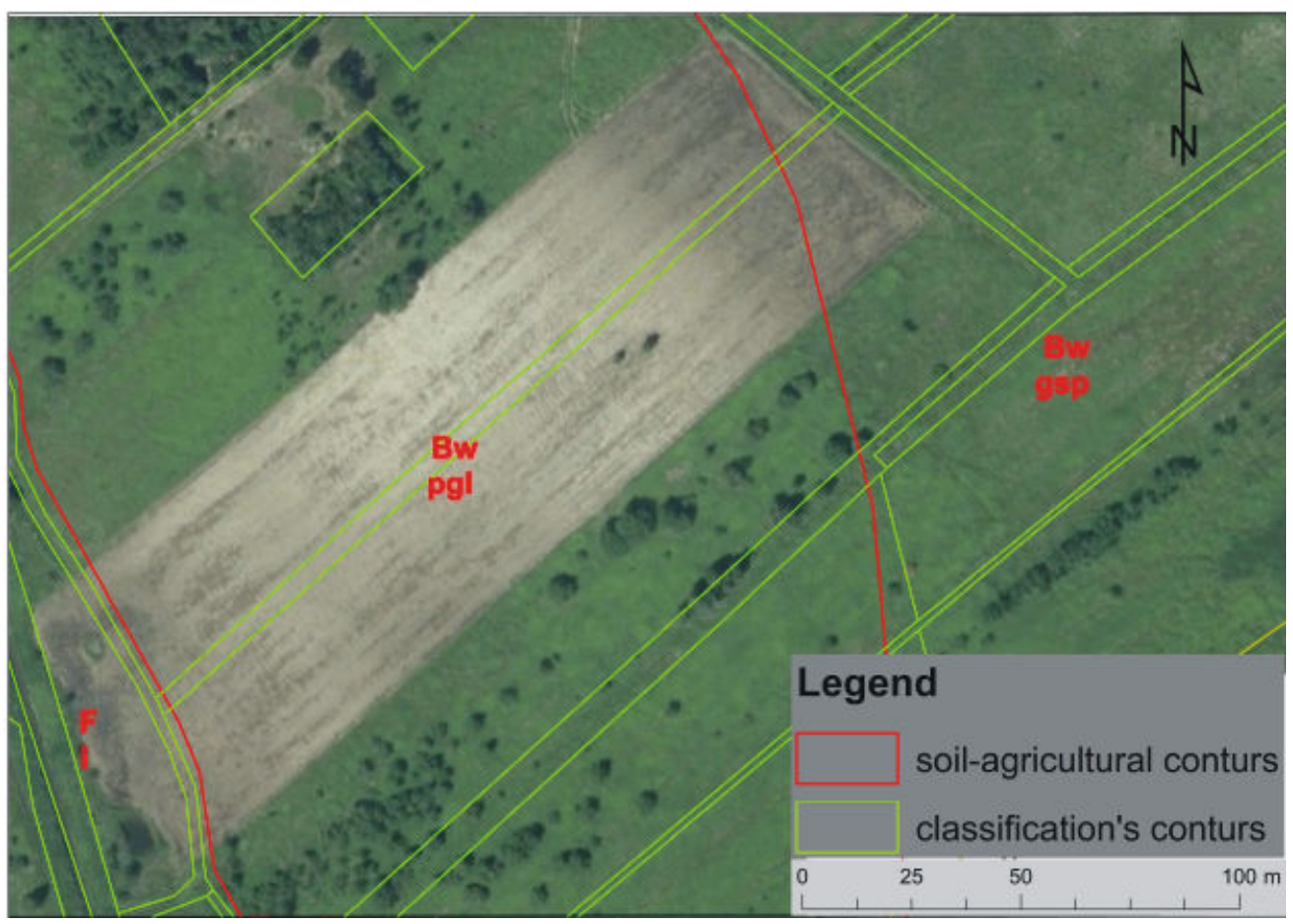

FIGURE 4. Visible belt of moist soil overlapping with the boundary of the soil-agricultural contour, own elaboration

tation of data from the soil-agricultural map with physical soil properties obtained, among others during laboratory research for the purposes of precise determination of cultivation measures, including liming and fertilisation, would permit database supplementation.

The application of soil quality contours (from the database of the land and building register), subject to statutory updates, determined with an accuracy to $0.5 \mathrm{~m}$, where data from soil-agricultural maps should be added to the descriptive part, would permit the supplementation of the missing parts important from the point of view of data application. This kind of solution would guarantee the obligatory character of all data updates, and consideration of changes resulting from the use of land would obtain more detailed information. Obtained results of field, laboratory and geostatistical tests confirm the current state of knowledge that the basic parameters affecting the soil spatial variability is the type of parent rock, closely related to the relief and soil moisture.

\section{CONCLUSIONS}

The database based on soil quality contours is more detailed than that based on the soil-agricultural map because no loss of important data concerning the division of land occurs. The problem resulting from the fact that one soil quality contour may contain several soil-agricultural contours should be solved through the analogical division of such contours. This would permit obtaining polygons designated with accuracy to $0.5 \mathrm{~m}$ containing descriptive attributes included in both the classification and soil-agricultural map. Obtaining data concerning the type of soil and/or agricultural usefulness complexes would require conducting the generalisation process.

It should be emphasised that the determination of the range of the spatial variability of soils is important in the case of use of soils as arable land. It can be applied particularly in precise agriculture or comparative estimate of land in the process of land consolidation and exchange, because in such measures, data concerning the quality and production capacity of soils are particularly important. For this purpose, based on soil quality contours supplemented by all descriptive attributes obtained from various sources, an application should be developed considering the fuzziness (spatial variability) of soil properties using known methods, including geostatistical methods and multicriteria analyses. Collection of data on soil conditions, however, based on soil quality contours, seems to be the best solution ensuring the proper degree of detail and data updating. 


\section{ACKNOWLEDGMENTS}

This research was completed within the framework The use of the soil-agricultural maps the scale of 1: 5000 for the assessment of the spatial variability of soil properties funded by the Dean of Faculty of Geodesy and Cartography, Project (No. 504/01929/ 1060/40.000XXX)

\section{DECLARATION}

Authors declare that there is no conflict of interests regarding the publication of his paper.

\section{REFERENCES}

Behrens T., Scholten T., 2006. Review Article digital soil mapping in Germany - a review. Journal of Plant Nutrition and Soil Science 169: 434-443.

Białousz S., Chmiel J., Fijałkowska A., Różycki S., 2010. Application of satellite photographs and GIS technology in updating soil-landscape units-examples for small-scale studies. Archive of Photogrammetry. Cartography and Remote Sensing 21: 21-32 (in Polish).

Bieganowski A., Witkowska-Walczak B., Gliński J., Sokołowska Z., Sławiński C., Brzezińska M. and Włodarczyk T., 2013. Database of Polish arable mineral soils: a review. International Agrophysics 27: 335-350.

Bielska A., Jaroszewicz J., 2012. Review of methods using fuzzy functions and multi-criteria analyses for the development of digital soil-agricultural maps. Acta Scientiarum Polonorum - Geodesia et Descriptio Terrarum 11 (2): 5-15 (in Polish).

Bombasaro E., Kasper T., 2016. Evaluation of spatial soil variability in the Pearl River Estuary using CPTU data. Soils and Foundations 56 (3): 496-505.

Bong T., Son Y., Noh S., Park J., 2014. Probabilistic analysis of consolidation that considers spatial variability using the stochastic response surface method. Soils and Foundations 54 (5): 917-926.

Brevik E.C., Calzolari C., Miller B.A., Pereira P., Kabala C., Baumgarten A., Jordán A., 2016. Soil mapping, classification, and pedologic modeling: History and future directions. Geoderma 264: 256-274.

Carré F., McBratney A., Mayr T., Montanarella L., 2007. Digital soil assessments: Beyond DSM. Geoderma 142: 69-79.

Cierniewski J., 1987. Zmienność przestrzenna czarnych ziem właściwych wycinka równiny kościańskiej określona na podstawie badań przekrojów glebowych. Roczniki Gleboznawcze - Soil Science Annual 38(4): 95-111.

De Gruijter J.J., Walvoort D.J.J., Bragato G., 2011. Application of fuzzy logic to Boolean models for digital soil assessment. Geoderma 166 (1): 15-33.

Dobers E.S., Ahl Ch., Stuczyński T., 2010. Comparison of Polish and German maps of agricultural soil quality using GIS. Journal of Plant Nutrition and Soil Science 173 (2): 185-197.

European Commission, 2005. Soil Atlas of Europe. European Soil Bureau Network, Office for Official Publications of the European Communities: 128 pp.
Gooley L., Huang J., Page D., Triantafilis J., 2013. Digital soil mapping of available water content using proximal and remotely sensed data. Soil Use and Management 30 (1): 139151.

Kaźmierowski C., Spychalski M., Kaczmarek Z., 2006. Accuracy of the indirect methods of hydraulic conductivity estimation in selected soils of Wielkopolska provence. Roczniki Gleboznawcze - Soil Science Annual 57(3/4): 55-65.

Krasowicz S., Oleszek S., Horabik J., Dębicki R, Jankowiak J., Stuczyński T., Jadczyszyn J., 2011. Racjonalne gospodarowanie środowiskiem glebowym Polski. Polish Journal of Agronomy 7: 43-58 (in Polish).

Kutilek M., Jendele L., Panayiotopoulos K.P., 2006. The influence of uniaxial compression upon pore size distribution in bi-modal soils. Soil Till. Res. 86: 27-37.

Kuźnicki F., Białousz S., Skłodowski P., 1979. Basics of soil science with elements of soil cartography. PWN, Warszawa (in Polish).

Kwiatkowska-Malina J., 2009. Transformations of organic substances introduced into soils. (Malina G. (Editor). Reclamation and revitalisation of degraded areas. PZiTS o. wielkopolski: 127-140 (in Polish).

Maciejewska A., 1994. Research on the properties and fertility of sandy soil after the application of unconventional fertiliser obtained from lignite. Wydawnictwo ART, Olsztyn: 67 (in Polish).

Minasny B., McBratney A.B., 2016. Digital soil mapping: A brief history and some lessons. Geoderma 264: 301-311.

Nussbaum M., Ettlin L., Çöltekin A., Suter B., Egli M., 2011. The Relevance of Scale in Soil Maps. Bulletin BGS 32: 6370.

Panagos P., Jones A., Bosco C., Senthil Kumar P.S., 2011. European digital archive on soil maps (EuDASM): Preserving important soil data for public free access. International Journal of Digital Earth 4(5): 434-443.

Polish Soil Classification (Systematyka Gleb Polski), 1989. Roczniki Gleboznawcze - Soil Science Annual 40(3/4): 1-150 (in Polish with English summary).

Reynolds W.D., Bowman B.T., Drury C.F., Tan C.S., Lu X., 2002. Indicators of good soil quality: density and storage parameters. Geoderma 110 (1-2): 131-146.

Rozporządzenie Ministra Spraw Wewnętrznych i Administracji z dnia 9 listopada 2011 r. w sprawie standardów technicznych wykonywania geodezyjnych pomiarów sytuacyjnych i wysokościowych oraz opracowywania i przekazywania wyników tych pomiarów do państwowego zasobu geodezyjnego i kartograficznego (Dz.U. 2011 nr 263 poz. 157).

Shukla M.K., Lal R., Ebinger M., 2006. Determining soil quality indicators by factor analysis. Soil and Tillage Research 87 (2): 194-204.

Strategy, 2014. Strategy of economic development of the Czermin commune for the years 2015-2020 (in Polish).

Strzemski M., Bartoszewski Z., Czarnowski F., Dombek E., Siuta J., Truszkowska R., Witek T., 1964. Manual for the preparation of soil-agricultural maps at a scale of 1:5000 and 1:25000 and soil-environmental maps at a scale of 1:25000. Attachment to Regulation No. 115 of the Minister of Agriculture of 28 July 1964 on the organisation of soil study- and agricultural-cartographic works (Journal of Laws of the Ministry of Agriculture No. 19, item 121), Warszawa (in Polish). 
Teng M., Zeng L., Xiao W., Huang Z., Zhou Z., Yan Z., Wang P., 2017. Spatial variability of soil organic carbon in Three Gorges Reservoir area, China. Science of The Total Environment 599-600: 1308-1316.

Usowicz B., Marczewski W., Łukowski M.I., Lipiec J., Usowicz J.B., 2011. Assessment of soil moisture from ground measurements and satellite data in ESA SMOS mission, conference materials of the $28^{\text {th }}$ Congress of the Polish Soil Science Society. Soil-Human-Environment: 5-50 (in Polish).

Usowicz B., Hajnos M., Sokołowska Z., Józefaciuk G., Bowanko G., Kossowski J., 2004. Spatial variability of physical and chemical soil properties at a scale of a field and commune. Acta Agrofizyka, Rozprawy i monografie: 103 pp. (in Polish). Vasu D., Singh S.K., Sahu N., Tiwary P., Chandran P., Duraisami V.P., Ramamurthy V., Lalitha M., Kalaiselvi B., 2017. Assessment of spatial variability of soil properties using geospatial techniques for farm level nutrient management. Soil and Tillage Research 169: 25-34.
Wade S.D., Foster I.D.L., Baban S.M.J., 1996. The spatial variability of soil nitrates in arable and pasture landscapes: implications for the development of geographical information system models of nitrate leaching. Soil Use and Management 12(2): 95-101.

Walczak R., Ostrowski J., Witkowska-Walczak B., Sławiński C., 2002. Hydrophysical characteristics of mineral cultivation soils in Poland. Acta Agrophysica 79: 1-64 (in Polish).

Warrick A.W., 2002. Soil physics companion. CRC Press LLC, Boca Raton, USA.

website 2012: http://geoportaal.maaamet.ee/eng/Maps-and-Data/ Estonian-Soil-Map-p316.html.

Received: March 13, 2018

Accepted: April 15, 2019

Associated editor: P. Hulisz

\section{Mapy glebowe w skali 1:5000 jako źródło bazy danych o glebach z uwzględnieniem rozmycia gleb w Polsce}

Streszczenie: Analiza zmienności (rozmycia) właściwości przestrzennych gleb jest istotna dla interpretacji konturów glebowych, nie tylko w procesie badań, ale także do modelowania gleb. Celem pracy była ocena przydatności map glebowo-rolniczych i klasyfikacyjnych w skali 1: $5000 \mathrm{w}$ kontekście identyfikacji czynników determinujących przestrzenną zmienność gleb. Jest to szczególnie ważne z punktu widzenia kosztochłonności i pracochłonności wiarygodnego określania zasięgu konturów glebowych. Badania przeprowadzono w gminie Czermin (województwo podkarpackie) z wykorzystaniem metod geostatystycznych i interpretacji materiałów źródłowych, w tym: (i) cyfrowej mapy glebowo-rolniczej, (ii) załącznika do mapy glebowo-rolniczej w skali 1: 5000, (iii) konturów klasyfikacyjnych, oraz (iv) cyfrowego modelu terenu. Weryfikacji wyników prac kameralnych w terenie (poligon testowy), podczas których wykonano odkrywki glebowe z pionowym przekrojem, dokonano poprzez określenie układu poziomów genetycznych i ich cech morfologicznych. Pobrano próbki glebowe do badań laboratoryjnych, w których oznaczono podstawowe właściwości fizyczne gleb (uziarnienie). Dane analizowano za pomocą statystyki opisowej i geostatystyki. Baza danych oparta na konturach klasyfikacyjnych jest bardziej szczegółowa od bazy danych opartej na mapie glebowo-rolniczej, ponieważ nie traci się istotnych danych dotyczących podziału na użytki gruntowe. Uzyskanie danych dotyczących rodzaju gleby i kompleksów przydatności rolniczej wymagałoby przeprowadzenia procesu uogólniania. Określenie zakresu przestrzennej zmienności gleb jest istotne przede wszystkim w przypadku gruntów ornych.

Słowa kluczowe: gleba, zmienność przestrzenna, właściwości fizyczne, geostatystyka, kompleks przydatności rolniczej, kontur glebowo-rolniczy 